\title{
Effect of Zirconia Content on the 0 xidation Behavior of Silicon Carbide/Zirconia/Mullite Composites
}

\author{
Cheng-Yuan Tsai and Chien-Cheng Lin*,† \\ Department of Materials Science and Engineering, National Chiao Tung University, \\ Hsinchu 300, Taiwan \\ Avigdor Zangvil $^{*}$ \\ Materials Research Laboratory and Department of Materials Science and Engineering, University of Illinois, \\ Urbana, Illinois 61801 \\ Ai-K ang Li ${ }^{*}$ \\ Materials Research Laboratory, ITRI, Chutung 310, Taiwan
}

\begin{abstract}
The oxidation of hot-pressed $\mathrm{SiC}$-particle $\left(\mathrm{SiC}_{\mathrm{p}}\right)$ /zirconia $\left(\mathrm{ZrO}_{2}\right) /$ mullite composites with various $\mathrm{ZrO}_{2}$ contents, exposed in air isothermally at $1000^{\circ}$ and $1200^{\circ} \mathrm{C}$ for up to 500 $h$, was investigated; an emphasis was placed on the effects of the $\mathrm{ZrO}_{2}$ content on the oxidation behavior. A clear critical volume fraction of $\mathrm{ZrO}_{2}$ existed for exposures at either $1000^{\circ}$ or $1200^{\circ} \mathrm{C}$ : the oxidation rate increased dramatically at $\mathrm{ZrO}_{2}$ contents of $>20$ vol $\%$. The sharp transition in the oxidation rate due to the variation of $\mathrm{ZrO}_{2}$ content could be explained by the percolation theory, when applied to the oxygen diffusivity in a randomly distributed two-phase medium. Morphologically, the composites with $\mathrm{ZrO}_{2}$ contents greater than the critical value showed a large oxidation zone, whereas the composites with $\mathrm{ZrO}_{2}$ contents less than the critical value revealed a muchthinner oxidation zone. The results also indicated that the formation of zircon $\left(\mathrm{ZrSiO}_{4}\right)$ at $1200^{\circ} \mathrm{C}$, through the reaction between $\mathrm{ZrO}_{2}$ and the oxide product, could reduce the oxidation rate of the composite.
\end{abstract}

\section{Introduction}

$\mathrm{C}$ ERAMICS are promising materials for making structural components for use at elevated temperatures. Specifically, mullite has been considered to be one of the best candidates, because of its good high-temperature strength, high creep resistance, good thermal-shock resistance, excellent chemical stability, and low theoretical density. However, the low fracture toughness $\left(\sim 2 \mathrm{MPa} \cdot \mathrm{m}^{1 / 2}\right)$ has limited its use. One of the remedies is the incorporation of reinforcements. Partially stabilized zirconia (PSZ) and various forms of silicon carbide (SiC), such as particles, whiskers, and fibers, have shown their effectiveness in toughening mullite. ${ }^{1-5}$ Because mullite-matrix composites are considered for use in high-temperature environments, their oxidation behavior, as well as the ensuing degradation of their mechanical properties, is of great concern.

N. S. Jacobson—contributing editor

\footnotetext{
Manuscript No. 191493. Received May 15, 1997; approved December 8, 1997. Supported by the National Science Council of Taiwan under Grant No. NSC830405-E-009-006. Author AZ was supported by the U.S. Dept. of Energy, Materials Science Division, under Grant No. DE-FG02-91ER45439.

*Member, American Ceramic Society.

${ }^{\dagger}$ Author to whom correspondence should be addressed.
}

The oxidation of monolithic $\mathrm{SiC}$ has been subjected to investigation in the last few decades. Previous studies suggested that the inward diffusion of oxygen through the growing oxide layer was the rate-controlling step. ${ }^{6-11}$ Under such a condition, linear-parabolic oxidation kinetics were obeyed: the oxide thickness was initially proportional to time and then to the square root of time. The oxidation behavior of SiC-reinforced ceramic-matrix composites has also been investigated. ${ }^{12-24}$ Porter and Chokshi ${ }^{19}$ examined the oxidation behavior of an 18-vol\%-SiC-whisker-reinforced alumina $\left(\mathrm{Al}_{2} \mathrm{O}_{3}\right)$ composite at temperatures in the range of $1500^{\circ}-1700^{\circ} \mathrm{C}$. They reported that mullite formed because of interaction between the matrix and the oxidation product. In a study on the oxidation of $\mathrm{SiC}_{\mathrm{p}} /$ $\mathrm{Al}_{2} \mathrm{O}_{3}$ and $\mathrm{SiC}_{\mathrm{p}} /$ mullite composites at $1375^{\circ}-1575^{\circ} \mathrm{C}$, Luthra and Park ${ }^{16}$ found a parabolic rate behavior, and the parabolic rate constant increased as the $\mathrm{SiC}$ content in the composites increased. Two reaction products, i.e., mullite and an amorphous aluminosilicate, were observed in the oxidized $\mathrm{SiC}_{\mathrm{p}} /$ $\mathrm{Al}_{2} \mathrm{O}_{3}$ composite, and some partially oxidized $\mathrm{SiC}$ particles were found between the reaction product layer and the unoxidized zone. Kriven et $a l^{20}$ found that $\mathrm{SiC}$ whisker $\left(\mathrm{SiC}_{\mathrm{w}}\right) /$ $\mathrm{Al}_{2} \mathrm{O}_{3}$ composites had a faster oxidation rate than $\mathrm{SiC}_{\mathrm{w}} /$ mullite composites, whereas Borom and co-workers ${ }^{13,14}$ emphasized that the oxidation behavior of SiC-reinforced alumina- or mullite-matrix composites was affected by the reaction of the oxidation product and matrix.

There were some studies on the oxidation behavior of zirconia-containing $\left(\mathrm{ZrO}_{2}\right.$-containing) composites as well. Backhaus-Ricoult ${ }^{18}$ stated that the microstructure of SiC-reinforced $\mathrm{ZrO}_{2} / \mathrm{Al}_{2} \mathrm{O}_{3}$ composites after exposure in air could be characterized by three typical subscales: (i) a glassy aluminosilicate in the outermost surface; (ii) an intermediate white scale with $\mathrm{Al}_{2} \mathrm{O}_{3}, \mathrm{ZrO}_{2}$, reaction products (mainly mullite), and large pores; and (iii) an inner black scale that contained zircon $\left(\mathrm{ZrSiO}_{4}\right)$, partially "dissolved" $\mathrm{SiC}$ whiskers, and carbon. Liu et $a l .{ }^{21}$ claimed that the oxidation rate of a $\mathrm{SiC}_{\mathrm{w}} / \mathrm{ZrO}_{2} /$ mullite composite was faster than that of a $\mathrm{SiC}_{\mathrm{w}} /$ mullite composite, because of the reduced crystallization rate in silica $\left(\mathrm{SiO}_{2}\right)$ by the existence of $\mathrm{ZrO}_{2}$. $\mathrm{Lin}^{22}$ and Lin et al. ${ }^{23,24}$ found that the oxidation rate of some $\mathrm{SiC}_{\mathrm{w}} / \mathrm{ZrO}_{2} /$ mullite composites was much faster than that of a $\mathrm{SiC}_{\mathrm{w}} /$ mullite composite, because of higher oxygen diffusion in $\mathrm{ZrO}_{2}$, which provided a rapid transport route of oxygen in the $\mathrm{ZrO}_{2}$-containing matrices. Therefore, addition of PSZ particles into the mullite matrix, as an effective toughening phase, could cause degradation of the oxidation resistance of the $\mathrm{SiC}_{\mathrm{w}} /$ mullite composite. Oxidation versus depth behavior was studied for several composites, and oxidation modes were defined and quantified based on plots of 
oxide-layer thickness (around whiskers) versus depth. ${ }^{22-24}$ However, they studied only composites with $\sim 30 \% \mathrm{ZrO}_{2}$ and did not elucidate the effect of $\mathrm{ZrO}_{2}$ content on the oxidation behavior of $\mathrm{SiC}_{\mathrm{w}} / \mathrm{ZrO}_{2} /$ mullite composites.

In the present study, hot-pressed $\mathrm{SiC}_{\mathrm{p}} / \mathrm{ZrO}_{2} /$ mullite composites are exposed isothermally in air at $1000^{\circ}$ and $1200^{\circ} \mathrm{C}$. The purpose is to investigate the effect of the matrix composition, i.e., the variation of $\mathrm{ZrO}_{2}$ content, on the oxidation behavior of $\mathrm{SiC}_{\mathrm{p}} / \mathrm{ZrO}_{2} /$ mullite composites. The effect of the formation of $\mathrm{ZrSiO}_{4}$, as a result of the interaction between $\mathrm{ZrO}_{2}$ and the oxidation product, on the oxidation rate is also investigated.

\section{Experimental Procedure}

Composites of $\mathrm{SiC}_{\mathrm{p}} /$ mullite and $\mathrm{SiC}_{\mathrm{p}} / \mathrm{ZrO}_{2} /$ mullite, all of which contained $30 \mathrm{vol} \%$ of $\mathrm{SiC}$ particulates, were fabricated by hot pressing. The starting materials were commercial mullite powder $(0.2 \mu \mathrm{m}$ average particle size, KM-mullite, Kyoritsu Ceramic Materials Co., Nagoya, Japan), 3 mol\% $\mathrm{Y}_{2} \mathrm{O}_{3}$ partially stabilized $\mathrm{ZrO}_{2}(0.3 \mu \mathrm{m}$ average particle size, Product No. TZ-3Y, Toyo Soda Mfg. Co., Tokyo, Japan), and SiC powder (7 $\mu \mathrm{m}$ average particle size, Cerac, Milwaukee, WI). Powder mixtures of desired composition were dispersed and homogenized by using an ultrasonic dispersing process (Model XL-2020, SONICATOR ${ }^{\circledR}$, Heat Systems, Farmingdale, NY) with methanol as a medium. To form a stable suspension, the $\mathrm{pH}$ of each slurry was adjusted to 10 with ammonium hydroxide $\left(\mathrm{NH}_{4} \mathrm{OH}\right)$. The slurry was partially dried on a hot plate under continuous stirring and oven-dried thereafter. The dried, crushed, and sieved powder mixtures were uniaxially prepressed into disks $60 \mathrm{~mm}$ in diameter. The green compact was then coated with boron nitride (BN) and placed into a graphite die that was lined with graphite foil. The composites that contained various contents of $\mathrm{ZrO}_{2}$ were hot-pressed at $1600^{\circ} \mathrm{C}$ in an argon atmosphere under a pressure of $30 \mathrm{MPa}$ for $45 \mathrm{~min}$. The designations, compositions, and hot-pressing conditions of the composites are listed in Table I. For the sake of convenience, the "zirconia + mullite" portion in each $\mathrm{SiC}_{\mathrm{p}} / \mathrm{ZrO}_{2} /$ mullite composite is called the "matrix," even though this matrix itself is a composite. The matrix, either mullite or zirconia + mullite, has a content of $70 \mathrm{vol} \%$ in each composite, whereas the $\mathrm{ZrO}_{2}$ content is expressed as a volume percentage of the matrix only, rather than a volume percentage of the entire composite (see footnotes in Table I).

The as-hot-pressed composites were ground and then cut into pieces with dimensions of $10 \mathrm{~mm} \times 6 \mathrm{~mm} \times 3 \mathrm{~mm}$. All specimens were ground and polished with diamond paste and weighed before and after oxidation using a precision electronic balance (Model R200D, Satorius AG, Goettingen, Germany); the balance was accurate to $0.01 \mathrm{mg}$. Composite samples were exposed to air in a box furnace (Model 51333, Lindberg, Watertown, WI) isothermally at $1000^{\circ}$ and $1200^{\circ} \mathrm{C}$ for up to 500 h. Specimens were loaded into the furnace at room temperature, and then the furnace temperature was increased at a rate of $20^{\circ} \mathrm{C} / \mathrm{min}$ until the set temperature was attained. One specimen for each composition was drawn from the furnace at various intervals to measure the weight change. Specimens drawn from the furnace were not reloaded for further oxidation, to avoid the formation of extended cracks due to thermal shock. The extent of oxidation was expressed by the weight change per unit surface area (called weight gain hereafter).

The major phases on the surfaces of the as-hot-pressed specimens and the exposed specimens were identified via X-ray diffractometry (XRD) (Model MXP18, Mac Science, Tokyo, Japan). The as-polished cross sections of oxidized specimens were observed by using polarized light microscopy (Model BH-2, Olympus, Tokyo, Japan) as well as by using a scanning electron microscopy (SEM) microscope (Model S-2500, Hitachi, Tokyo, Japan) that was equipped for energy-dispersive $\mathrm{X}$-ray spectroscopy (EDS) (Kevex Instruments, Valencia, CA).

\section{Results}

Figure 1 shows the plots of weight gain versus time for various $\mathrm{SiC}_{\mathrm{p}} / \mathrm{ZrO}_{2} /$ mullite composites after exposure at $1000^{\circ}$ and $1200^{\circ} \mathrm{C}$, respectively. The weight gain increased as time increased for each composite at $1000^{\circ}$ and $1200^{\circ} \mathrm{C}$. The weight gains of the composites that contained $<20$ vol\% $\mathrm{ZrO}_{2}$ were significantly less than those of the composites that contained $\geq 30$ vol\% $\mathrm{ZrO}_{2}$. Figure 2 shows the relationship between the weight gain and the volume fraction of $\mathrm{ZrO}_{2}$ for exposure at $1000^{\circ} \mathrm{C}$ for $500 \mathrm{~h}$ and $1200^{\circ} \mathrm{C}$ for $500 \mathrm{~h}$. This figure indicates that the weight gains for the composites that contained $<20$ vol\% $\mathrm{ZrO}_{2}$ were comparatively small, whereas the weight gain increased rapidly when the composites contained $>20$ vol\% $\mathrm{ZrO}_{2}$. It appeared that there was a critical volume fraction of $\mathrm{ZrO}_{2}$ content required for rapid oxidation. In other words, the oxidation rate would be accelerated abruptly beyond this critical $\mathrm{ZrO}_{2}$ content, whereas the weight gain remained fairly low below the critical value. It is also noted that the weight-gain curve for $1200^{\circ} \mathrm{C}$ slightly declined as the $\mathrm{ZrO}_{2}$ content increased to $>80 \mathrm{vol} \%$.

Figure 3 shows the XRD spectrum of the surface of the as-hot-pressed MZY50/SiC composite, as well as the XRD spectra after exposure for $500 \mathrm{~h}$ at $1000^{\circ}$ and $1200^{\circ} \mathrm{C}$. The as-hot-pressed sample consisted of four major phases: mullite, monoclinic $\mathrm{ZrO}_{2}\left(\mathrm{~m}-\mathrm{ZrO}_{2}\right)$, tetragonal $\mathrm{ZrO}_{2}\left(\mathrm{t}-\mathrm{ZrO}_{2}\right)$, and $\mathrm{SiC}$ (Fig. 3(a)). After exposure at $1000^{\circ} \mathrm{C}$ for $500 \mathrm{~h}$, the matrix was rather stable; i.e., the interaction between the oxide product and the matrix was insignificant (Fig. 3(b)). No new crystalline phases were found. However, observations via transmission electron microscopy (TEM) in a previous study 22 indicated that there was an amorphous $\mathrm{SiO}_{2}$ layer around each of $\mathrm{SiC}$ particles located near the surface of the composite. As shown in

Table I. Designation, Compositions, and Hot-Pressing Conditions of Composites

\begin{tabular}{llc}
\hline \multicolumn{1}{c}{ Designation } & \multicolumn{1}{c}{ Composition ${ }^{\dagger}$} & $\begin{array}{c}\text { Hot-pressing } \\
\text { conditions }\end{array}$ \\
\hline MZY0/SiC & Mullite $+30 \mathrm{vol} \% \mathrm{SiC}$ & $1675^{\circ} \mathrm{C} / 45 \mathrm{~min}$ \\
MZY5/SiC & (Mullite $+5 \mathrm{vol} \%$ 3Y-PSZ) $+30 \mathrm{vol} \% \mathrm{SiC}$ & $1600^{\circ} \mathrm{C} / 45 \mathrm{~min}$ \\
MZY10/SiC & (Mullite $+10 \mathrm{vol} \%$ 3Y-PSZ) $+30 \mathrm{vol} \% \mathrm{SiC}$ & $1600^{\circ} \mathrm{C} / 45 \mathrm{~min}$ \\
MZY15/SiC & (Mullite $+15 \mathrm{vol} \%$ 3Y-PSZ) $+30 \mathrm{vol} \% \mathrm{SiC}$ & $1600^{\circ} \mathrm{C} / 45 \mathrm{~min}$ \\
MZY20/SiC & (Mullite $+20 \mathrm{vol} \%$ 3Y-PSZ) $+30 \mathrm{vol} \% \mathrm{SiC}$ & $1600^{\circ} \mathrm{C} / 45 \mathrm{~min}$ \\
MZY25/SiC & (Mullite $+25 \mathrm{vol} \%$ 3Y-PSZ) $+30 \mathrm{vol} \% \mathrm{SiC}$ & $1600^{\circ} \mathrm{C} / 45 \mathrm{~min}$ \\
MZY30/SiC & (Mullite $+30 \mathrm{vol} \%$ 3Y-PSZ) $+30 \mathrm{vol} \% \mathrm{SiC}$ & $1600^{\circ} \mathrm{C} / 45 \mathrm{~min}$ \\
MZY40/SiC & (Mullite $+40 \mathrm{vol} \%$ 3Y-PSZ) $+30 \mathrm{vol} \% \mathrm{SiC}$ & $1600^{\circ} \mathrm{C} / 45 \mathrm{~min}$ \\
MZY50/SiC & (Mullite $+50 \mathrm{vol} \%$ 3Y-PSZ) $+30 \mathrm{vol} \% \mathrm{SiC}$ & $1600^{\circ} \mathrm{C} / 45 \mathrm{~min}$ \\
MZY60/SiC & (Mullite $+60 \mathrm{vol} \%$ 3Y-PSZ) $+30 \mathrm{vol} \% \mathrm{SiC}$ & $1600^{\circ} \mathrm{C} / 45 \mathrm{~min}$ \\
MZY80/SiC & (Mullite $+80 \mathrm{vol} \%$ 3Y-PSZ) $+30 \mathrm{vol} \% \mathrm{SiC}$ & $1600^{\circ} \mathrm{C} / 45 \mathrm{~min}$ \\
MZY100/SiC & 3Y-PSZ $+30 \mathrm{vol} \% \mathrm{SiC}$ & $1600^{\circ} \mathrm{C} / 45 \mathrm{~min}$ \\
\hline
\end{tabular}

"The volume percentage of the matrix in parentheses is $70 \%$ for each composite; the balance is $\mathrm{SiC}_{\mathrm{p}}$. $\mathrm{The} \mathrm{ZrO}_{2}$ content is based on the matrix itself; i.e., the amount (in vol\%) of Y-PSZ $=$ volume of Y-PSZ $\times 100 /($ volume of mullite + volume of Y-PSZ). ${ }^{\star}$ All hot pressing was performed under a pressure of $30 \mathrm{MPa}$ and under a $1 \mathrm{~atm}$ argon-gas atmosphere. 

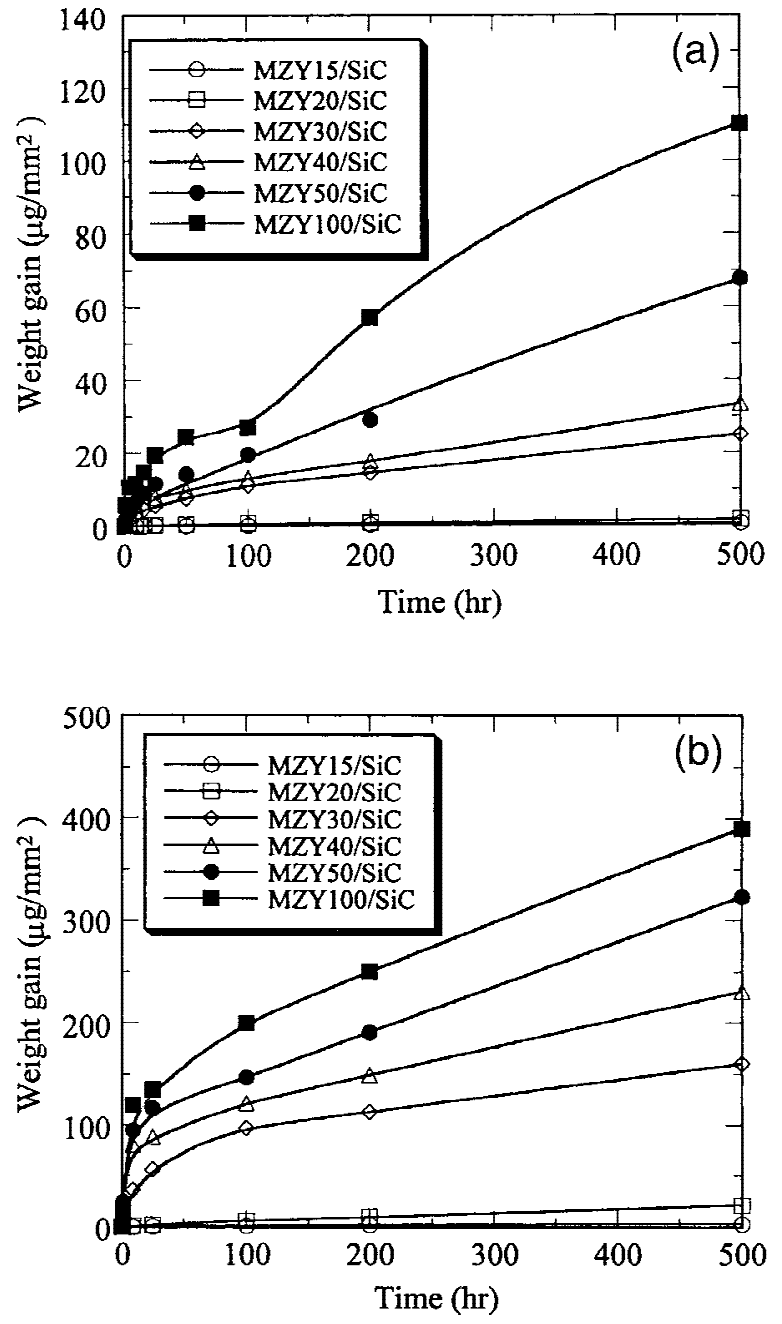

Fig. 1. Curves of weight gain versus time at (a) $1000^{\circ}$ and (b) $1200^{\circ} \mathrm{C}$ for samples listed in Table I.

Fig. 3(c), after exposure at $1200^{\circ} \mathrm{C}$ for $500 \mathrm{~h}$, some stronger diffracted peaks of cristobalite were identified, whereas $\mathrm{ZrSiO}_{4}$ was also found (due to the interaction between $\mathrm{SiO}_{2}$ and $\mathrm{ZrO}_{2}$ ), which led to the reduction of the $\mathrm{ZrO}_{2}$ peak intensities. Figure 4 shows the XRD spectra of composites with various $\mathrm{ZrO}_{2}$ contents after exposure at $1200^{\circ} \mathrm{C}$ for $500 \mathrm{~h}$. It is apparent that the relative intensity of the corresponding $\mathrm{ZrSiO}_{4}$ peaks increased as the $\mathrm{ZrO}_{2}$ content increased.

Figure 5 shows polarized-light optical micrographs of the MZY15/SiC composite (for $500 \mathrm{~h}$ ), the MZY20/SiC composite (for $500 \mathrm{~h}$ ), and the MZY50/SiC composite (for $25 \mathrm{~h}$ ), all after exposure at $1200^{\circ} \mathrm{C}$. The cross-sectional samples clearly exhibited a distinct layered structure; this layering was due to the different extent of oxidation at various depths, which caused a change in composition. Figure 5(a) reveals the cross section of the MZY15/SiC composite; it has two oxidized surfaces that are glued together, the interfaces of which are located at the center of the micrograph. The oxidation zone consists of an outer white scale and an inner black scale, whereas the gray region is the unoxidized substrate. Figure 5(b) demonstrates a two-layer structure for the MZY20/SiC composite; both the white and black scales are thicker than the corresponding scales in the MZY15/SiC composite (Fig. 5(a)). Figure 5(c) shows the $\mathrm{MZY} 50 / \mathrm{SiC}$ composite after exposure at $1200^{\circ} \mathrm{C}$ for $25 \mathrm{~h}$; this figure indicates much-thicker white and black regions (the unoxidized region is not shown). Figure 6 shows an SEM micrograph of the cross section of the MZY20/SiC composite after exposure at $1200^{\circ} \mathrm{C}$ for $500 \mathrm{~h}$. The outermost surface of the composite is shown on the left. The bright particles are $\mathrm{ZrO}_{2}$ embedded in the mullite matrix (shown as the gray regions in the figure). Angular SiC particles were encompassed by a dark layer (indicated by the arrow). The dark layer was identified as being the oxidation product, $\mathrm{SiO}_{2}$. The variation of the oxidation of $\mathrm{SiC}$ particles with depth is also observed. There is a sharp change in the thickness of the $\mathrm{SiO}_{2}$ layer at a depth of $\sim 45 \mu \mathrm{m}$. The outer region ("A-B") corresponds to the white scale shown in Fig. 5(b), whereas the inner region (" $\mathrm{B}-\mathrm{C}$ ") corresponds to the black scale in Fig. 5(b).

Figures 7 and 8 demonstrate the effect of $\mathrm{ZrO}_{2}$ content on the oxidation morphology of $\mathrm{SiC}_{\mathrm{p}} / \mathrm{ZrO}_{2} /$ mullite composites. Figure 7 shows an SEM micrograph of the MZY15/SiC composite after exposure at $1200^{\circ} \mathrm{C}$ for $500 \mathrm{~h}$, indicating that $\mathrm{SiC}$ particles at a depth beyond $\sim 40 \mu \mathrm{m}$ did not oxidize noticeably. That is, there was a small oxidation zone in the MZY15/SiC composite after exposure at $1200^{\circ} \mathrm{C}$ for $500 \mathrm{~h}$. Figure 8 shows a series of micrographs for the $\mathrm{MZY} 30 / \mathrm{SiC}$ composite at various depths after exposure at $1200^{\circ} \mathrm{C}$ for $25 \mathrm{~h}$. The $\mathrm{SiC}$ particles were slightly oxidized, even at a depth of $>600 \mu \mathrm{m}$, which indicates a much-larger oxidized depth than that of the MZY15/SiC composite exposed for $500 \mathrm{~h}$.

\section{Discussion}

For the sake of convenience in our discussion, two terms are first defined. First, the silica layer of an individual $\mathrm{SiC}$ particle in a $\mathrm{SiC}$-containing composite means the layer of $\mathrm{SiO}_{2}$ that is formed as a result of the oxidation reaction occurring on the surface of the $\mathrm{SiC}$ particle. When a $\mathrm{SiC}$ particle is partially oxidized, a silica layer will encompass it. Second, the oxidation zone of a SiC-containing composite after exposure in an oxidizing environment is defined as the zone from the outermost surface of the composite to the depth where no oxidation of the incorporated $\mathrm{SiC}$ particles can be detected.

The inward diffusion of oxygen from the atmosphere causes the oxidation of $\mathrm{SiC}$ particles within the oxidation zone, which results in weight gain, because of the formation of $\mathrm{SiO}_{2}$, according to the reaction

$$
\mathrm{SiC}(s)+\frac{3}{2} \mathrm{O}_{2}(g) \rightarrow \mathrm{SiO}_{2}(s)+\mathrm{CO}(g)
$$

where most of the gaseous product $\mathrm{CO}$ was believed to diffuse all the way out to the surface. Thus, the atomic-weight difference between the $\mathrm{SiC}$ and $\mathrm{SiO}_{2}$ was the reason for the weight gain during oxidation, and the extent of oxidation could be represented by the weight gain of each sample. In contrast, no weight gain was detected in the oxidation test of mullite and $\mathrm{ZrO}_{2}$ /mullite composites, ${ }^{22}$ which indicates that the inward diffusion of oxygen was negligible in the composites that contained no $\mathrm{SiC}$.

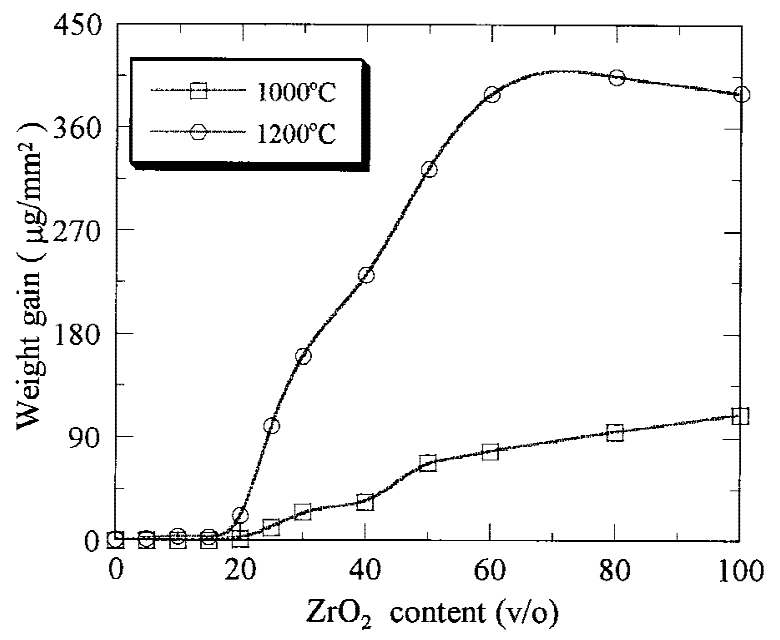

Fig. 2. Curves of weight gain versus $\mathrm{ZrO}_{2}$ content at $1000^{\circ}$ and $1200^{\circ} \mathrm{C}$ for $500 \mathrm{~h}$. 


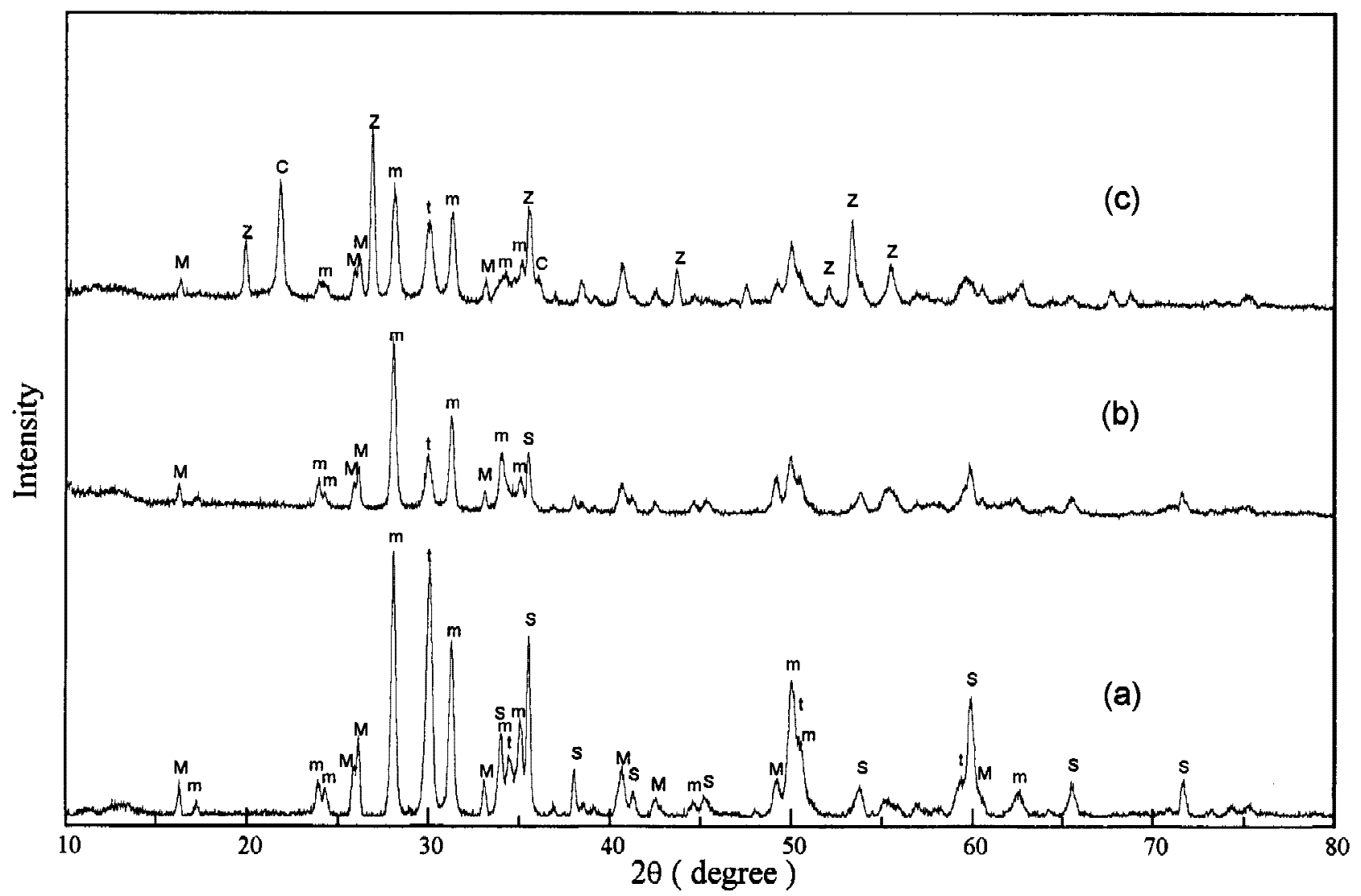

Fig. 3. XRD spectra of the MZY50/SiC composite (as hot-pressed (spectrum "(a)"), after exposure at $1000^{\circ} \mathrm{C}$ for $500 \mathrm{~h}$ (spectrum "(b)"), and after exposure at $1200^{\circ} \mathrm{C}$ for $500 \mathrm{~h}$ (spectrum “(c)" )). $\left(\mathrm{M}=\right.$ mullite, $\mathrm{Z}=$ zircon, $\mathrm{C}=$ cristobalite, $\mathrm{m}=\mathrm{m}-\mathrm{ZrO}_{2}, \mathrm{t}=\mathrm{t}-\mathrm{ZrO}{ }_{2}$, and $\mathrm{S}=\mathrm{SiC}$.)

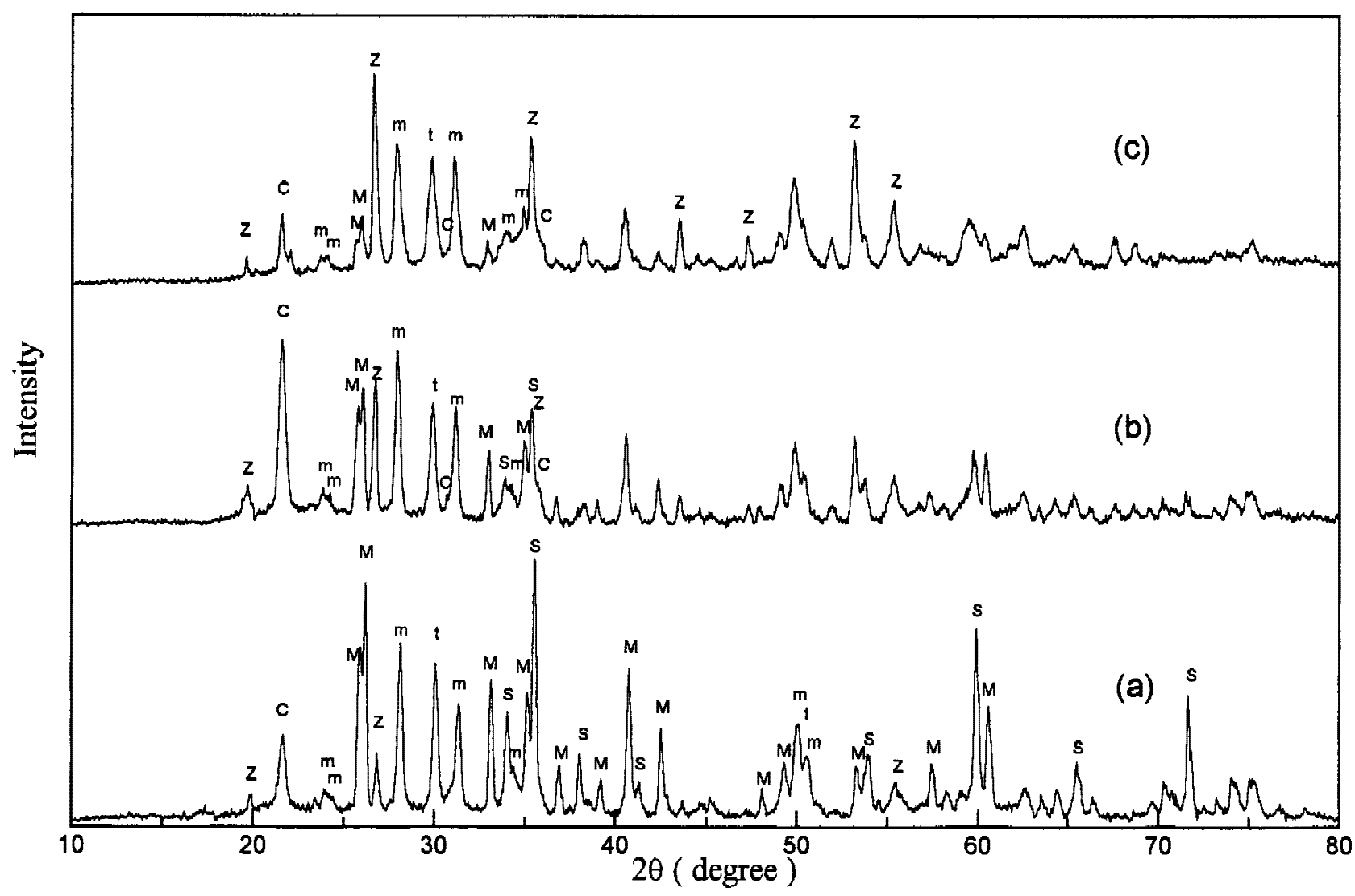

Fig. 4. XRD spectra of the MZY15/SiC (spectrum “(a)"), MZY25/SiC (spectrum “(b)"), and MZY50/SiC (spectrum “(c)") composites, all after exposure at $1200^{\circ} \mathrm{C}$ for $500 \mathrm{~h}$. $\left(\mathrm{M}=\right.$ mullite, $\mathrm{Z}=$ zircon, $\mathrm{C}=$ cristobalite, $\mathrm{m}=\mathrm{m}-\mathrm{ZrO}_{2}, \mathrm{t}=\mathrm{t}-\mathrm{ZrO}_{2}$, and $\mathrm{S}=\mathrm{SiC}$.) 

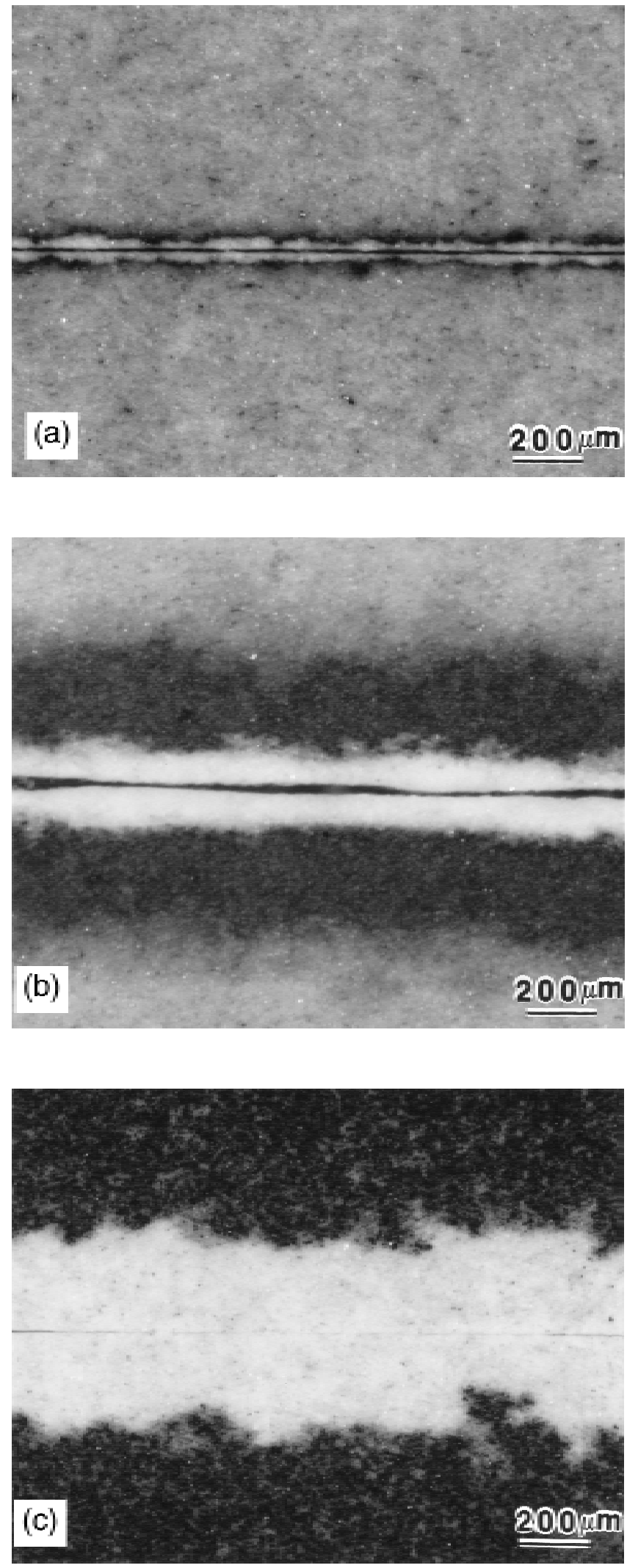

Fig. 5. Polarized-light optical micrographs of the (a) MZY15/SiC $\left(500 \mathrm{~h} / 1200^{\circ} \mathrm{C}\right)$, (b) $\mathrm{MZY} 20 / \mathrm{SiC}\left(500 \mathrm{~h} / 1200^{\circ} \mathrm{C}\right)$, and (c) $\mathrm{MZY} 50 / \mathrm{SiC}$ $\left(25 \mathrm{~h} / 1200^{\circ} \mathrm{C}\right)$ composites.

As shown in Figs. 1 and 2, the weight gain abruptly increased when the amount of incorporated $\mathrm{ZrO}_{2}$ was above a certain volume fraction. There appeared to be a threshold value of $\sim 20 \mathrm{vol} \% \mathrm{ZrO}_{2}$ for the oxidation rate of $\mathrm{SiC}_{\mathrm{p}} / \mathrm{ZrO}_{2} / \mathrm{mullite}$ composites. A plausible explanation for this phenomenon can be based on the percolation theory. ${ }^{25-27}$ It applies to a wide variety of transport phenomena, including diffusivity and thermal or electric conductivity. In a two-phase system, when one phase has a very high diffusivity of a species compared to that of the other phase, there exists a critical volume fraction, or percolation threshold $\left(f_{\mathrm{c}}\right)$, of the high-diffusivity phase. Percolation occurs beyond this threshold, and the diffusivity of the particular species in the composite has the order of magnitude of the high diffusivity. In other words, for a binary composite with $D_{2} \gg D_{1}$, percolation theory predicts that $D_{\mathrm{m}}$ has the approximate order of $D_{1}$ if $f<f_{\mathrm{c}}$ and has the approximate order of $D_{2}$ if $f>f_{\mathrm{c}}$ (where $D_{1}$ and $D_{2}$ are the diffusivities of a certain species in the two phases, $D_{\mathrm{m}}$ is the diffusivity of that species in the composite, and $f$ is the volume fraction of the second phase).

Because oxygen diffusivity in $\mathrm{ZrO}_{2}$ is much higher than that in mullite (Table II) and using mullite and $\mathrm{ZrO}_{2}$ as the first and second phases, respectively, the relationships of oxygen diffusivity in $\mathrm{ZrO}_{2} /$ mullite matrices would be

$$
\begin{array}{ll}
D_{\text {matrix }}^{\mathrm{O}} \approx \text { order of } D_{\text {zirconia }}^{\mathrm{O}} & \left(\text { if } f>f_{\mathrm{c}}\right) \\
D_{\text {matrix }}^{\mathrm{O}} \approx \text { order of } D_{\text {mullite }}^{\mathrm{O}} & \left(\text { if } f<f_{\mathrm{c}}\right)
\end{array}
$$

where the superscript denotes the diffusing species (oxygen). Note that the $\mathrm{ZrO}_{2}$ /mullite assembly is called the "matrix," because it serves as a matrix for the $\mathrm{SiC}_{\mathrm{p}}$. From the results shown in Figs. 1 and $2, f_{\mathrm{c}} \approx 20$ vol\% $\mathrm{ZrO}_{2}$. The oxygen diffusivity in a matrix with $>20 \mathrm{vol} \% \mathrm{ZrO}_{2}$ should be very close to that in $\mathrm{ZrO}_{2}$, which leads to a rapid increase in the oxidation rate of $\mathrm{SiC}$ particles. On the other hand, the diffusivities in matrices with $f<f_{\mathrm{c}}$ should be of the same order as that of mullite (which is very low); thus, $\mathrm{SiC}$ particles were better protected by these matrices.

In addition to the sharp transition at $f_{\mathrm{c}}$, the weight gain of $\mathrm{SiC}_{\mathrm{p}} / \mathrm{ZrO}_{2} /$ mullite composites also increased as the $\mathrm{ZrO}_{2}$ content increased, either when $f\left\langle f_{\mathrm{c}}\right.$ or when $f>f_{\mathrm{c}}$. For the oxidation of an "individual" $\mathrm{SiC}$ particle in $\mathrm{SiC}_{\mathrm{p}} / \mathrm{ZrO}_{2} /$ mullite composites, the inward diffusion of oxygen will proceed via the following serial steps: (i) oxygen diffuses through the $\mathrm{ZrO}_{2}$-containing matrix to the surface of $\mathrm{SiC}$, where the oxidation reaction occurs; and (ii) as the silica layer is formed, oxygen must further diffuse through it to arrive at the interface of the silica layer and the unoxidized $\mathrm{SiC}$ core. That is, the inward diffusion of oxygen may be controlled by either diffusion through the $\mathrm{ZrO}_{2}$-containing matrix or diffusion through the silica layer, depending on which one is slower. It is easy to compare the diffusivities of oxygen in $\mathrm{SiO}_{2}, \mathrm{ZrO}_{2}$, and mullite (Table II). At $1000^{\circ} \mathrm{C}$, the diffusivity in $\mathrm{ZrO}_{2}$ is between $10^{-9}$ and $10^{-5} \mathrm{~cm}^{2} / \mathrm{s}$; this value is dependent on crystal structure, additives, and the stoichiometry. ${ }^{28,29}$ At the same temperature, the diffusivity in amorphous silica is much lower $\left(10^{-13}-10^{-12}\right.$ $\left.\mathrm{cm}^{2} / \mathrm{s}\right) .^{30,31}$ The diffusivity in mullite is unknown. It was suggested by Cherkasoy et al. $^{32}$ (quoted by Luthra and Park ${ }^{16}$ ) to be similar to that in $\mathrm{Al}_{2} \mathrm{O}_{3}$, which, in turn, is between $10^{-20}$ and $10^{-18} \mathrm{~cm}^{2} / \mathrm{s}$ (based on reports quoted by Luthra and Park ${ }^{16}$ ). Oxygen diffusion in $\mathrm{Al}_{2} \mathrm{O}_{3}$, and possibly in mullite, being extremely slow in the bulk, is mainly through grain boundaries and, therefore, is strongly dependent on the microstructure. However, it may be safe to generally state that oxygen diffusivity in $\mathrm{SiO}_{2}$ is very small compared to that in $\mathrm{ZrO}_{2}$ but is very large compared to that in mullite. Therefore, if $f<f_{\mathrm{c}}$ (e.g., the MZY15/SiC composite), the oxygen diffusivity in the matrix is much lower than that in the silica layer and, thus, the oxidation rate is likely to be controlled by the oxygen diffusion in the matrix. More accurately, the controlling step is determined by the lowest reciprocal diffusion impedance, or diffusivity $(D)$ divided by the corresponding thickness. Most of the oxygen will be consumed continuously by the oxidizing $\mathrm{SiC}$ particles at or near the surface until they are completely oxidized, which results in a shallow oxidation zone. Because the oxygen diffusivity slowly increases as the $\mathrm{ZrO}_{2}$ content increases in the range of $f<f_{c}$, according to the effective medium theory, ${ }^{33,34}$ 


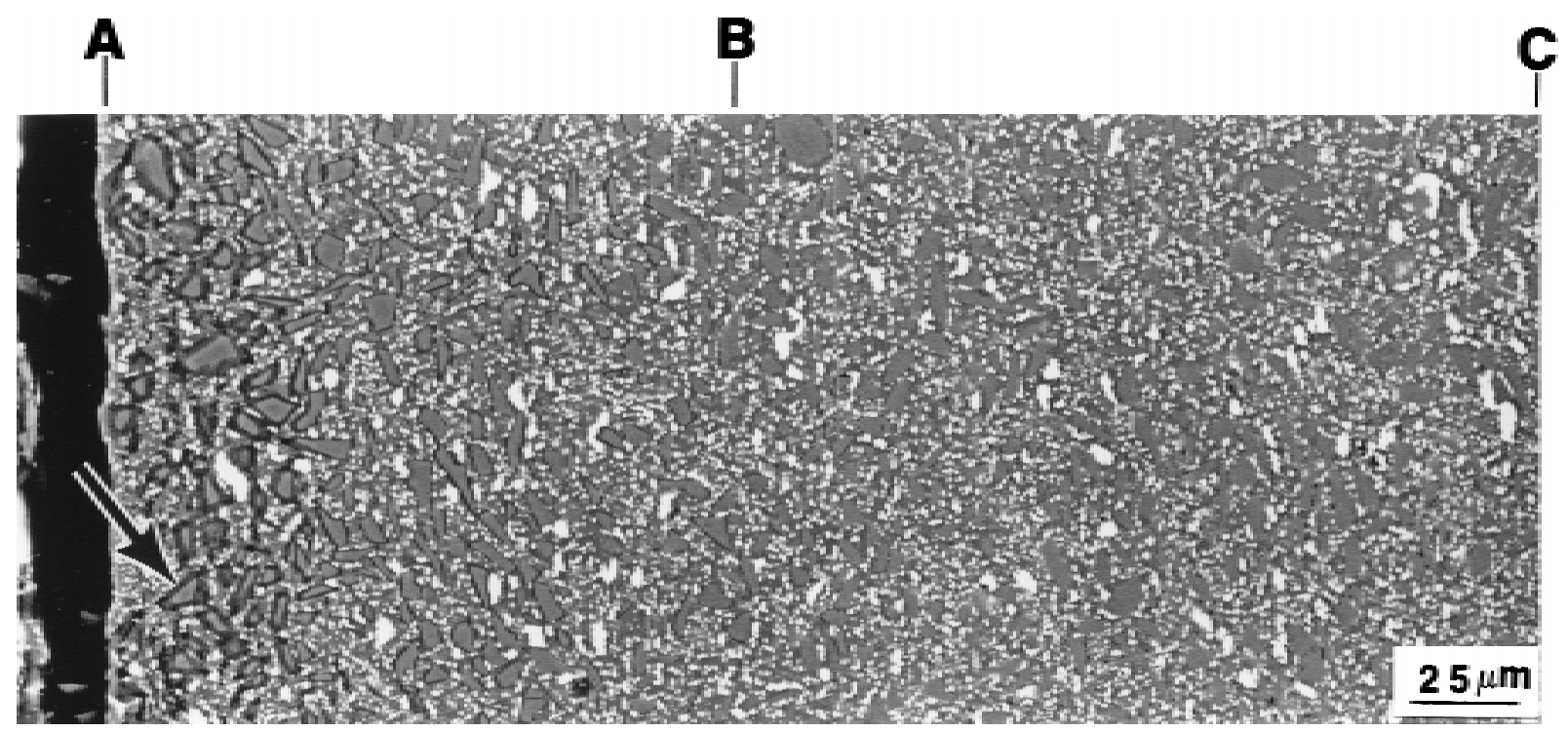

Fig. 6. SEM micrograph of a cross section of the MZY20/SiC composite after exposure at $1200^{\circ} \mathrm{C}$ for $500 \mathrm{~h}$, revealing a variation of the oxidation of $\mathrm{SiC}$ particles with depth: region "A-B" corresponds to the white layer in Fig. 5(b), and region "B-C" corresponds to the black layer in Fig. $5(\mathrm{~b})$.

it is inferred that the oxidation rate will also slowly increase as the $\mathrm{ZrO}_{2}$ content increases. This observation is consistent with the result as shown in Fig. 2. The oxidation mechanism and morphology, as described previously for the composites with $\mathrm{ZrO}_{2}$ contents less than the threshold value, are illustrated schematically in Fig. 9(a). However, when $f>f_{c}$, as it is in the MZY30/SiC composite, the oxidation of SiC particles at various depths will proceed in parallel. Because the oxygen diffusivity in the matrix now becomes much faster than that in the silica layer around $\mathrm{SiC}$, the oxygen will pass over partially oxidized $\mathrm{SiC}$ particles and continuously diffuse into the inner region, leading to the oxidation of more $\mathrm{SiC}$ particles and, thus, a deep oxidation zone. The oxidation mechanism and morphol-

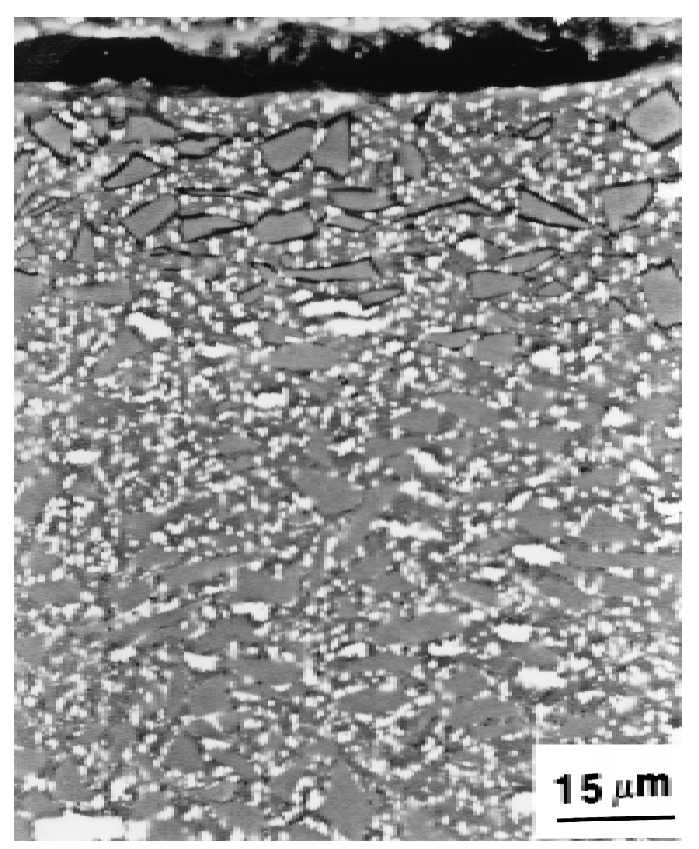

Fig. 7. SEM micrograph of a cross section of the MZY15/SiC composite after exposure at $1200^{\circ} \mathrm{C}$ for $500 \mathrm{~h}$, showing a small oxidation zone. ogy for the composites with $\mathrm{ZrO}_{2}$ contents greater than the threshold value are illustrated schematically in Fig. 9(b).

For the $\mathrm{SiC}_{\mathrm{p}} / \mathrm{ZrO}_{2} /$ mullite composites, the zircon $\left(\mathrm{ZrSiO}_{4}\right)$ phase was formed in samples exposed at $1200^{\circ} \mathrm{C}$ but not at $1000^{\circ} \mathrm{C}$. The reaction proceeded according to the equation

$$
\mathrm{SiO}_{2}+\mathrm{ZrO}_{2} \rightarrow \mathrm{ZrSiO}_{4}
$$

The mullite phase in the matrix was very stable and did not react with $\mathrm{SiC}$ or $\mathrm{ZrO}_{2} \cdot{ }^{22}$ However, at higher temperatures, such as $1200^{\circ} \mathrm{C}$, the oxidation product $\left(\mathrm{SiO}_{2}\right)$ would react with $\mathrm{ZrO}_{2}$ to form $\mathrm{ZrSiO}_{4}$, thus modifying the composition of the matrix. In other words, the formation of $\mathrm{ZrSiO}_{4}$ would cause the consumption of $\mathrm{ZrO}_{2}$ at the expense of $\mathrm{SiO}_{2}$. The oxygen diffusivity in $\mathrm{ZrSiO}_{4}$ is probably much slower than that in $\mathrm{ZrO}_{2}$. For example, the formation of a $\mathrm{ZrSiO}_{4}$ layer effectively stopped the increase in weight gain during the oxidation of a silicon oxynitride-zirconia $\left(\mathrm{Si}_{2} \mathrm{~N}_{2} \mathrm{O}-\mathrm{ZrO}_{2}\right)$ composite. ${ }^{35}$ Therefore, the substitution of $\mathrm{ZrO}_{2}$ by $\mathrm{ZrSiO}_{4}$ will slow the oxygen diffusion in the matrix, which leads to a decrease in the oxidation rate. The fact that the weight gain at $1200^{\circ} \mathrm{C}$ did not increase (or even slightly decrease) when the $\mathrm{ZrO}_{2}$ content was $>80$ vol\% (Fig. 2) may be attributed to the fact that more $\mathrm{ZrSiO}_{4}$ formed at higher $\mathrm{ZrO}_{2}$ contents, as determined by XRD (Fig. 4).

\section{Summary}

An evident critical volume fraction of $\sim 20$ vol\% $\mathrm{ZrO}_{2}$ existed in the $\mathrm{SiC}_{\mathrm{p}} / \mathrm{ZrO}_{2} /$ mullite composites after exposure in air isothermally at $1000^{\circ}$ and $1200^{\circ} \mathrm{C}$. The oxidation rate was much more rapid beyond this threshold. The dramatic change in oxidation rate due to the variation of $\mathrm{ZrO}_{2}$ content can be well explained by percolation theory. The $\mathrm{ZrO}_{2}$ content also had a strong influence on the oxidation morphology. The composites with $\mathrm{ZrO}_{2}$ contents less than the threshold value showed a small oxidation zone, whereas the composites with $\mathrm{ZrO}_{2}$ contents greater than the threshold value showed a large oxidation zone and a smooth variation of silica-layer thickness of $\mathrm{SiC}$ at various depths. In addition, the formation of $\mathrm{ZrSiO}_{4}$, as a result of the interaction between the matrix and the oxide product, would lead to a reduction of the oxidation rate. 

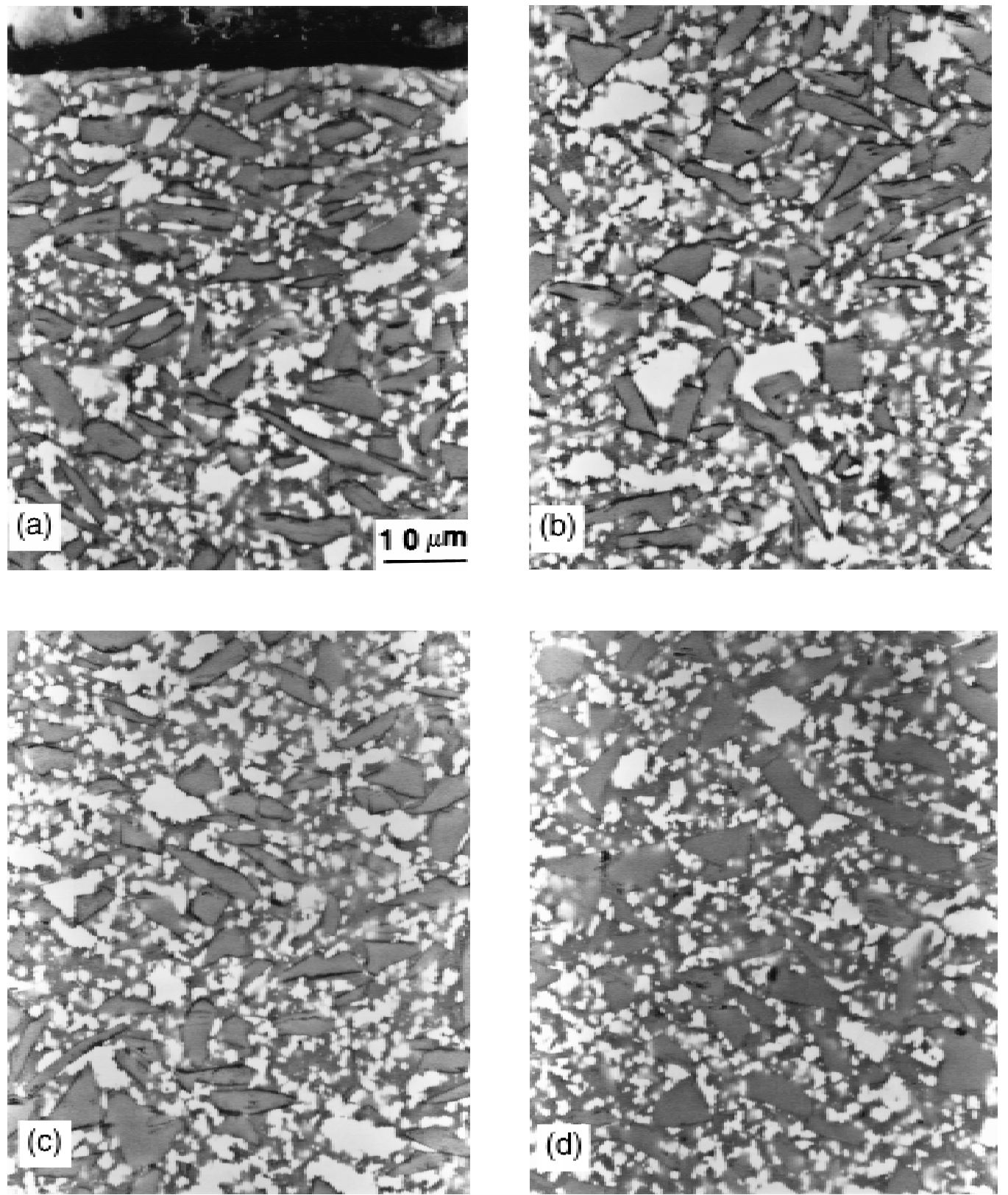

Fig. 8. SEM micrographs of a cross section of the $\mathrm{MZY} 30 / \mathrm{SiC}$ composite after exposure at $1200^{\circ} \mathrm{C}$ for $25 \mathrm{~h}$, showing a large oxidation zone (from the outermost surface to a depth of (a) $60 \mu \mathrm{m}$ (bottom of the micrograph), (b) $130 \mu \mathrm{m}$ (bottom of the micrograph), (c) $250 \mu \mathrm{m}$ (bottom of the micrograph), and (d) $670 \mu \mathrm{m}$ (bottom of the micrograph)).

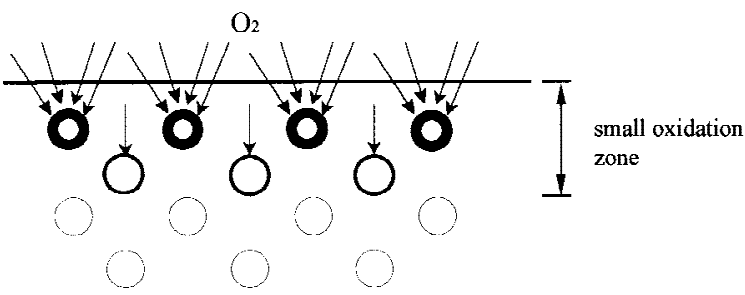

(a)

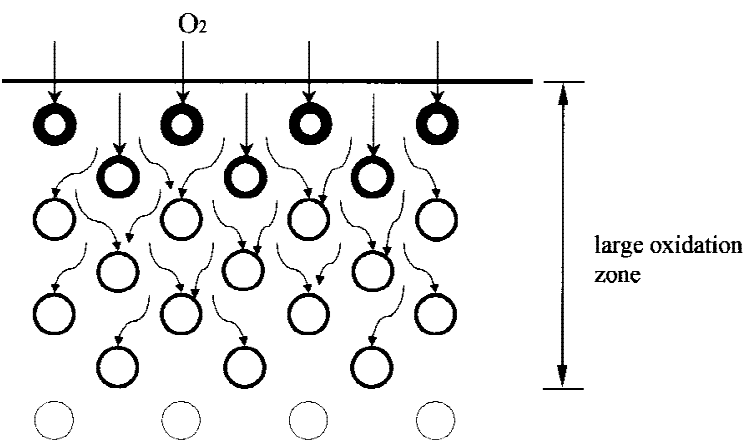

(b)

Fig. 9. Two distinct mechanisms for the oxidation of $\mathrm{SiC} / \mathrm{ZrO}_{2} /$ mullite composites are shown. When $f<f_{\mathrm{c}}$, the oxygen diffusivity in the matrix is much lower than that in the silica layer, so that most of the oxygen will be consumed continuously by the $\mathrm{SiC}$ particles located near the surface (Fig. 9(a)); a small oxidation zone is obtained. When $f>f_{\mathrm{c}}$, the oxygen diffusivity in the silica layer is much lower than that in the matrix, so that oxygen will pass over the partially oxidized $\mathrm{SiC}$ particles and enter into the inner region, causing more $\mathrm{SiC}$ particles to be oxidized (Fig. 9(b)); a large oxidation zone is obtained. 
Table II. Oxygen Diffusivities in Mullite, Zirconia, and Silica

\begin{tabular}{|c|c|c|c|}
\hline Material & $\begin{array}{c}\text { Diffusivity } \\
\left(\mathrm{cm}^{2} / \mathrm{s}\right)\end{array}$ & $\begin{array}{c}\text { Temperature } \\
\left({ }^{\circ} \mathrm{C}\right)\end{array}$ & Reference \\
\hline Mullite & $\sim 10^{-19}$ & 1000 & Estimated $^{\dagger}$ \\
\hline Zirconia & $\sim 10^{-9}$ & 1000 & Dou et al. ${ }^{28}$ and Kofstad ${ }^{29}$ \\
\hline Silica & $\sim 10^{-13}$ & 1000 & Norton $^{30}$ and Lamkin et al. ${ }^{31}$ \\
\hline
\end{tabular}

\section{References}

${ }^{1} \mathrm{P} . \mathrm{F}$. Becher and T. N. Tiegs, "Toughening Behavior Involving Multiple Mechanisms: Reinforcement and Zirconia Toughening," J. Am. Ceram. Soc., 70 [9] 651-54 (1987).

${ }^{2}$ P. F. Becher, C.-H. Hsueh, P. Angelini, and T. N. Tiegs, "Toughening Behavior in Whisker-Reinforced Ceramic Matrix Composites," J. Am. Ceram. Soc., 71 [12] 1050-61 (1988).

${ }^{3}$ G. C. Wei and P. F. Becher, "Development of SiC-Whisker-Reinforced Ceramics," Am. Ceram. Soc. Bull., 64 [2] 298-304 (1985).

${ }^{4}$ N. Claussen and J. Jahn, "Mechanical Properties of Sintered, In SituReacted Mullite-Zirconia Composites,'” J. Am. Ceram. Soc., 63 [3-4] 228-29 (1980).

${ }^{5}$ R. Ruh, K. S. Mazdiyasni, and M. G. Mendiratta, "Mechanical and Microstructural Characterization of Mullite and Mullite-SiC-Whisker and $\mathrm{ZrO}_{2}$ Toughened-Mullite-SiC-Whisker Composites,' J. Am. Ceram. Soc., 71 [6] 503-12 (1988).

${ }^{6} \mathrm{~J}$. A. Costello and R. E. Tressler, "Oxidation Kinetics of Hot-Pressed and Sintered $\alpha$-SiC,', J. Am. Ceram. Soc., 64 [6] 327-31 (1981).

${ }^{7}$ J. A. Costello and R. E. Tressler, "Oxidation Kinetics of Silicon Carbide Crystals and Ceramics: I, In Dry Oxygen,’ J. Am. Ceram. Soc., 69 [9] 674-81 (1986).

${ }^{8}$ G. Ervin, “'Oxidation Behavior of Silicon Carbide," J. Am. Ceram. Soc., 41 [9] 347-52 (1958).

9J. W. Hinze, W. C. Tripp, and H. C. Graham "'The High-Temperature Oxidation of Hot-Pressed Silicon Carbide,', ; pp. 409-19 in Materials Science Research, Vol. 9, Mass Transport Phenomena in Ceramics. Edited by A. R. Copper and A. H. Heuer. Plenum Press, New York, 1975.

${ }^{10} \mathrm{P}$. J. Jorgensen, M. E. Wadsworth, and I. B. Cutler, "Oxidation of Silicon Carbide," J. Am. Ceram. Soc., 42 [12] 613-16 (1959).

${ }^{11}$ P. J. Jorgensen, M. E. Wadsworth, and I. B. Cutler, "Effects of Oxygen Partial Pressure on the Oxidation of Silicon Carbide,' J. Am. Ceram. Soc., 43 [4] 209-12 (1960).

${ }^{12}$ C. Baudin and J. S. Moya, "Oxidation of Mullite-Zirconia-AluminaSilicon Carbide Composites,"' J. Am. Ceram. Soc., 73 [5] 1417-20 (1990).

${ }^{13}$ M. P. Borom, R. B. Bolon, and M. K. Brun, "Oxidation Mechanism of $\mathrm{MoSi}_{2}$ Particles Dispersed in Mullite,' Adv. Ceram. Mater., 3 [6] 607-11 (1988).

${ }^{14}$ M. P. Borom, M. K. Brun, and L. E. Szala, "Kinetics of Oxidation of Carbide and Silicide Dispersed Phases in Oxide Matrices," Adv. Ceram. Mater., 3 [5] 491-97 (1988).

${ }^{15}$ K. L. Luthra, "Chemical Interactions in High-Temperature Ceramic Composites," J. Am. Ceram. Soc., 71 [12] 1114-20 (1988).
${ }^{16}$ K. L. Luthra and H. D. Park, "Oxidation of Silicon Carbide-Reinforced Oxide-Matrix Composites at $1375^{\circ}$ to $1575^{\circ}$ C,' J. Am. Ceram. Soc., 73 [4] 1014-23 (1990)

${ }^{17}$ M. I. Osendi, "Oxidation Behaviour of Mullite-SiC Composites," J. Mater. Sci., 25, 3561-65 (1990).

${ }^{18}$ M. Backhaus-Ricoult, "Oxidation Behavior of SiC-Whisker-Reinforced Alumina-Zirconia Composites,"' J. Am. Ceram. Soc., 74 [8] 1793-802 (1991).

19J. R. Porter and A. H. Chokshi, "Creep Performance of Silicon Carbide Whisker-Reinforced Alumina"; pp. 919-28 in Ceramic Microstructure '86: Role of Interface. Edited by J. A. Pask and A. G. Evans. Plenum Press, New York, 1987.

${ }^{20}$ W. M. Kriven, G. van Tendeloo, T. N. Tiegs, and P. F. Becher, "Effect of High Temperature Oxidation on the Microstructure and Mechanical Properties of Whisker-Reinforced Ceramics"; ibid, pp. 939-47.

${ }^{21}$ H. Y. Liu, K. L. Weisskopf, M. J. Hoffmann, and G. Petzow, “Oxidation Behavior of SiC Whisker Reinforced Mullite $\left(-\mathrm{ZrO}_{2}\right)$ Composites,' J. Eur Ceram. Soc., 5, 122-33 (1989).

${ }^{22}$ C. C. Lin, "Microstructural Development, Phase Stability, and Toughening in Mullite Matrix Composites"' (Chs. 4-6); Ph.D. Thesis. University of Illinois, Urbana, IL, 1991.

${ }^{23}$ C. C. Lin, A. Zangvil, and R. Ruh, "Phase Stability and Oxidation Behavior of Mullite-SiC Whisker Composites"'; presented at the 91st Annual Meeting of the American Ceramic Society, Indianapolis, IN, April 1989 (Paper 7-JII-89)

${ }^{24}$ C. C. Lin, A. Zangvil, and R. Ruh, "Modes of Oxidation in SiC-Reinforced Mullite/ZrO 2 Based Composites: Oxidation vs. Depth Behavior'; unpublished work.

${ }^{25}$ S. R. Broadbent and J. M. Hammersley, "Percolation Processes I. Crystals and Mazes,' Proc. Cambridge Philos. Soc., 53 [3] 629-41 (1957).

${ }^{26}$ V. K. S. Shante and S. Kirkpatrick, "An Introduction to Percolation Theory,' Adv. Phys., 20 [85] 325-57 (1971).

${ }^{27}$ S. Kirkpatrick, "Percolation and Conduction," Rev. Mod. Phys., 45 [4] 574-88 (1973).

${ }^{28}$ S. Dou, C. R. Masson, and P. D. Pacey, "Induction Period for Oxygen Permeation Through Calcia-Stabilized Zirconia Ceramic," J. Am. Ceram. Soc. 72 [7] 1114-18 (1989).

${ }^{29} \mathrm{P}$. Kofstad, "Oxides of Group IVA Elements"; pp. 152-65 in Nonstoichiometry, Diffusion, and Electrical Conductivity in Binary Metal Oxides. Robert E. Krieger Publishing, Malabar, FL, 1983.

${ }^{30}$ F. J. Norton, "Permeation of Gaseous Oxygen through Vitreous Silica," Nature (London), 191 [4789] 701 (1961).

${ }^{31}$ M. A. Lamkin, F. L. Riley, and R. J. Fordham, "Oxygen Mobility in Silicon Dioxide and Silicate Glasses: A Review,' J. Eur. Ceram. Soc., 10, 347-67 (1992)

${ }^{32}$ P. A. Cherkasoy, W. A. Ficher, and C. Pieper, "Oxygen Permeability of Solid Electrolytes and Its Effect on the Electrochemical Determination of the Activity of Oxygen in Gases and Liquid Metals" (in Ger.), Arch. Eisenhuettenwes., 42, 873-76 (1971).

${ }^{33}$ H. T. Davis, L. R. Valencourt, and C. E. Johnson, "Transport Processes in Composite Media,’ J. Am. Ceram. Soc., 58 [9-10] 446-52 (1975).

${ }^{34}$ D. S. McLachlan, "Equation for the Conductivity of Macroscopic Mixture," J. Phys. C: Solid State Phys., 19 [9] 1339-54 (1986).

${ }^{35} \mathrm{C}$. O'Meara, M. Heim, and R. Pompe, "The Oxidation Behaviour of a Porous $\mathrm{Si}_{2} \mathrm{~N}_{2} \mathrm{O}-\mathrm{ZrO}_{2}$ Composite Material," J. Eur. Ceram. Soc., 15, 319-28 (1995). 